De Jure: Jurnal Hukum dan Syar'iah

Vol. 11, No. 2, 2019, h. 100-112

ISSN (Print): 2085-1618, ISSN (Online): 2528-1658

DOI: http://dx.doi.org/10.18860/j-fsh.v11i2.7297

Available online at http://ejournal.uin-malang.ac.id/index.php/syariah

\title{
Penegakan Hukum Terhadap Pemalsuan Identitas Dalam Pembatalan Perkawinan
}

\author{
Muhammad Jazil Rifqi \\ UIN Sunan Ampel Surabaya, Indonesia \\ muhammadjazilrifqi@uinsby.ac.id
}

\begin{abstract}
:
A marriage aims to form a family that is sakinah mawaddah wa rahmah. A valid marriage must be qualified and harmonious set out in Islamic law and statute. Nevertheless, it is not uncommon marriage should be annulled by the courts because it has a legal disability. The Factors causing the cancellation of marriage need to be elaborated by taking a sample of the decisions in several East Java Religious Courts in providing solutive offers in reducing or eliminating the same event in the future. This study is a normative legal research using law enforcement theoretical approach of Larwance M. Friedman in corelated with the decisions in several East Java Religious Courts. The result shows that the main factor of marital cancellation is due to identity forgery. Therefore, the acculturation of Lawrance M. Friedman and Jimly Asshiddiqie's ideas can be an alternative offer in the progressive family law to be better.

Pernikahan memiliki tujuan membentuk keluarga yang sakinah mawaddah wa rahmah. Perkawinan yang sah harus memenuhi syarat dan rukun yang ditetapkan dalam hukum Islam dan undang-undang. Meskipun demikian, tidak jarang perkawinan harus dibatalkan oleh pengadilan karena memiliki cacat hukum. Berbagai faktor penyebab pembatalan perkawinan perlu dielaborasi dengan mengambil sampel putusan di beberapa Pengadilan Agama Jawa Timur untuk memberikan penawaran solutif dalam mereduksi atau menghilangkan kejadian yang sama di waktu mendatang. Studi ini merupakan jenis peneliatian hukum normatif dengan putusan-putusan di beberapa Pengadilan Agama Jawa Timur. Hasil penelitian menyimpulkan bahwa faktor utama dari pembatalan perkawinan dikarenakan adanya pemalsuan identitas. Oleh karenanya, akulturasi gagasan Lawrance M. Friedman dan Jimly Asshiddiqie bisa menjadi tawaran alternatif dalam hukum keluarga progresif untuk menjadi lebih baik.
\end{abstract}

Kata Kunci: sistem hukum; pemalsuan identitas; pembatalan perkawinan.

\section{Pendahuluan}

Perkawinan merupakan upaya membentuk keluarga yang kekal dan bahagia sebagaimana diamanatkan Undang-Undang Nomor 1 Tahun 1974 tentang Perkawinan. 
Hal ini menunjukkan bahwa perkawinan bukan hanya dilakukan dalam jangka waktu tertentu. Friedman menyatakan bahwa setiap regulasi memiliki tujuan langsung dan tidak langsung. Begitu pula dengan peraturan perkawinan di Indonesia. Tujuan langsung dari peraturan perkawinan yaitu apa yang harus dilakukan atau tidak dilakukan. Misalnya memenuhi rukun dan syarat bagi yang hendak melangsungkan pernikahan. Sementara tujuan tidak langsungnya adalah apa yang diharapkan seseorang dalam pernikahan setelah melaksanakan semua prosedurnya, yakni rumah tangga yang sakinah mawaddah wa rahmah. ${ }^{1}$

Namun demikian, tidak semua ikatan perkawinan dapat berjalan sesuai harapan sebelum seseorang menikah. Indonesia, sebagai negara hukum, tidak terlepas untuk meregulasikan bagaimana prosedur yang harus ditempuh oleh tiap-tiap anggota masyarakat ketika mengakhiri pernikahannya, yang tentunya diperlukan suatu badan peradilan yang berfungsi untuk menegakkan hukum dan keadilan. Dalam hal ini, Pengadilan Agama merupakan pelaksana kekuasaan kehakiman yang bertugas dan berwenang memeriksa, dan memutus perkara perdata bagi umat Islam. Salah satu perkara yang ditanganinya adalah perkawinan akan batal/dapat dibatalkan jika tidak memenuhi rukun atau syarat sebuah perkawinan sebagaimana yang ditetapkan dalam Undang-Undang Perkawinan dan Kompilasi Hukum Islam (KHI). ${ }^{2}$ Artinya bahwa perkawinan tidak batal dengan sendirinya melainkan harus berdasarkan prosedur yang ada dan setelah pihak-pihak yang berkepentingan atau pejabat yang ditunjuk untuk mengajukan pembatalan perkawinan setelah mengetahui adanya suatu pelanggaran hukum atau adanya cacat dalam baik rukun maupun syarat perkawinan yang kemudian memohon kepada Pengadilan Agama di domisili daerah perkawinan tersebut dilangsungkan. ${ }^{3}$

Beberapa kasus perkawinan tidak harus dibatalkan karena mengelabui petugas institusi perkawinan. Konsekuensi bagi para pihak yang perkawinannya dibatalkan akan kembali ke status semula sebab perkawinannya dianggap tidak pernah ada (never come to being), sehingga pihak yang bersangkutan dapat menikah lagi secara sah dikemudian hari. ${ }^{4}$ Meskipun demikian, tentu saja terdapat pihak-pihak yang merasa sangat dirugikan karena tidak adanya sanksi, melainkan demi ketertiban dan menanamkan kesadaran masyarakat, hanya sekedar membatalkan perkawinan sebagai tujuan akhirnya. Gagasan bahwa negara segera menemukan standar hukum yang jauh lebih membumi sangat diperlukan masyarakat. ${ }^{5}$

Hal tersebut didasarkan akibat terpengaruh pandangan individualistik, yakni hukum cenderung dimanfaatkan, bahkan, melakukan penyalahgunaan hukum secara sengaja demi kepentingan pribadinya yang pada gilirannya merugikan orang lain. Oleh karenanya, yang perlu diperhatikan tidak hanya substansi hukum dan struktur hukum

\footnotetext{
${ }^{1}$ Lawrence M. Friedman, Legal System, The: A Social Science Perspective (New York: Russell Sage Foundation, 1975), 50.

${ }^{2}$ Abdurrahman, Kompilasi hukum Islam di Indonesia (Jakarta: Akademika Pressindo, 2010), 60.

3 Ahrum Hoerudin, Pengadilan agama: bahasan tentang pengertian, pengajuan perkara, dan kewenangan pengadilan agama setelah berlakunya UU No. 7 Tahun 1989 Tentang Peradilan Agama (Bandung: Citra Aditya Bakti, 1999), 13-14.

${ }^{4}$ R. D. Moses Komela Avan, Kebatalan Perkawinan: Pelayanan Hukum Gereja Dalam Proses Menyatakan Kebatalan Perkawinan (Yogyakarta: Kanisius, 2014), 14.

${ }^{5}$ Friedman, Legal System, 20.
} 
semata, tetapi juga budaya hukum (perilaku masyarakat) juga perlu diperbaiki. Karena sebaik apapun peraturan diundangkan, keberhasilan hukum juga ditentukan oleh budaya hukum masyarakat bersangkutan serta penyelenggara hukumnya. ${ }^{6}$ Tetapi, jika budaya hukum dan struktur hukum tidak mendukung berlakunya peraturan perundanganundangan yang ada, maka hukum tersebut hanyalah tulisan diatas lembaran-lembaran yang tidak bermakna. ${ }^{7}$

Ada beberapa penelitian terdahulu yang memiliki setengah kesamaan fokus dari kajian ini yang perlu diungkap, seperti : Kristy Button dkk, yang menemukan pembubaran perkawinan berbasis hukum adat dengan lokus di empat provinsi pedesaan Afrika Selatan setelah tahun 2000 masih membawa ketidakadilan bagi wanita. ${ }^{8}$ Penelitian ini juga memiliki distingsi dengan tulisan Abd. Holik, ${ }^{9}$ Deni Rahmatillah dan A.N Khifify, ${ }^{10}$ serta Faisal. ${ }^{11}$ Untuk meningkatkan status wanita, Abd. Holik menolak poligami yang tidak sesuai peraturan yang berlaku. Sementara Deni dan Khifify hanya mengungkap konsep pembatalan perkawinan yang tertuang dalam UUP dan KHI. Terakhir, meski terdapat kesamaan fokus dengan tulisan Faisal, yakni dengan menerangkan status pribadi yang tidak benar saat pendaftaran, pelaksanaan, dan paskapernikahan akan menjadi persoalan yang rumit bila dikemudian hari terungkap, yakni dengan mengajukan pembatalan perkawinan. Tulisan ini menggunakan teori Lawrance M Friedman sebagai pembeda dari tulisan-tulisan sebelumnya yang akan dijelaskan lebih lanjut dalam metode penelitian.

\section{Metode Penelitian}

Penelitian ini merupakan jenis pelitian hukum normatif dengan mengulas beberapa putusan pembatalan perkawinan dari berbagai Pengadilan Agama di Jawa Timur sebagai bahan primernya yang kemudian dianlisis menggunakan pola pikir induksi. Tulisan ini menggunakan pendekatan teori sistem hukum Lawrence $\mathrm{M}$. Friedman untuk melihat baik atau tidaknya penegakan hukum terkait pembatalan perkawinan yang dalam operasinya terdiri dari substansi hukum (legal substance), struktur hukum (legal structure), dan budaya hukum (legal culture) yang saling berinteraksi. Ketiga komponen tersebut merupakan satu-kesatuan dalam melakukan upaya penegakan hukum. Adalah sangat tidak baik, jika substansi hukumnya telah memiliki peradaban, namun tanpa disertai pelaksanaan struktur hukum yang mendukung. Demikian pula, kinerja struktur hukum yang memadai, tetapi sama sekali

\footnotetext{
6 Any Ismayawati, "Pengaruh Budaya Hukum Terhadap Pembangunan Hukum Di Indonesia (Kritik Terhadap Lemahnya Budaya Hukum Di Indonesia)," PRANATA HUKUM 6, no. 1 (January 31, 2011): 56-59, http://jurnal.ubl.ac.id/index.php/PH/article/view/154.

${ }^{7}$ Ismayawati, 64.

${ }^{8}$ Kirsty Button, Elena Moore, and Chuma Himonga, "South Africa's System of Dispute Resolution Forums: The Role of the Family and the State in Customary Marriage Dissolution," Journal of Southern African Studies 42, no. 2 (March 3, 2016): 299-316, https://doi.org/10.1080/03057070.2016.1148390.

9 Abd Holik, "Pembatalan Perkawinan Akibat Poligami," Tafáqquh: Jurnal Penelitian Dan Kajian Keislaman 1, no. 2 (December 1, 2013): 62-65.

${ }^{10}$ Deni Rahmatillah and A. N. Khofify, "Konsep Pembatalan Perkawinan Dalam Undang-Undang Nomor 1 Tahun 1947 Dan Kompilasi Hukum Islam," Hukum Islam 17, no. 2 (March 29, 2018): 152, https://doi.org/10.24014/hi.v17i2.4985.

${ }^{11}$ Faisal Faisal, "Pembatalan Perkawinan Dan Pencegahannya," Al-Qadha 4, no. 1 (August 23, 2017): 115 .
} 
tidak didukung dengan peraturan-peraturan yang baik, akan terjadi ketimpangan dalam masyarakat. Selain kedua komponen tersebut, budaya hukum juga sangat perlu diperbaiki, agar ketiganya berjalan dengan seimbang. Karena pada dasarnya, sikap individu dalam masyarakat terhadap substansi hukum dapat dipengaruhi oleh budaya hukum. ${ }^{12}$ Adapun struktur hukum merupakan elemen dasar, kerangka kerja, tubuh institusi dari sistem hukum, dalam hal ini dapat dikatakan sebagai sistem peradilan, yang difungsikan masyarakat dalam menyelesaikan sengketa atau mencari keadilan. Sementara substansi hukum tersusun atas peraturan bagaimana struktur hukum dan budaya hukum berperilaku. ${ }^{13}$ Fitur-fitur tersebut merupakan output legal system, yang pada intinya harus menjamin hak individu atau kelompok, karena hadirnya sistem hukum merupakan tuntutan masyarakat untuk mengeliminir induk ketidakadilan. ${ }^{14}$

\section{Hasil dan Pembahasan}

\section{Pembatalan Perkawinan: Substansi Hukum dan Struktur Hukum}

Substansi hukum meliputi peraturan-peraturan legal, baik tertulis maupun tidak tertulis, baik hukum in-concreto (kaidah hukum individual), maupun in-abstracto (kaidah hukum umum). ${ }^{15}$ Jadi, substansi hukum yuridis pembahasan ini tertuang dalam Undang-Undang Nomor 1 tahun 1974, PP nomor 9 tahun 1975 tentang pelaksanaan Undang-Undang Perkawinan, dan Kompilasi Hukum Islam. Beberapa aturan tersebut menyatakan bahwa ketika rukun dan syarat pernikahan terpenuhi, perkawinan menjadi sah. Sebaliknya, perkawinan tidak sah ketika rukun dan syarat pernikahan tidak terpenuhi. Rukun merupakan sesuatu yang harus ada dalam perkawinan, sementara syarat adalah sesuatu yang ada di dalam rukun perkawinan. Rukun pertama, dalam undang-undang perkawinan rmeliputi calon suami dan calon istri. Syaratnya, pertama, bagi calon laki-laki minimal umur 19 tahun, sementara bagi calon perempuan minimal berumur 16 tahun. Kedua, berlangsungnya pernikahan tidak didasarkan keterpaksaan. Rukun kedua adalah wali nikah bagi calon mempelai wanita, dengan syarat adanya hak atas perwaliannya dan tidak ada halangan perwalian seperti muslim, Aqil dan Baligh. Rukun ketiga yaitu dua orang saksi, dengan syarat laki-laki muslim, adil, aqil, baligh, ingatannya tidak terganggu, hadir dan memahami maksud akad pernikahan. Rukun terakhir adalah ijab kabul, dimana ijab diutarakan oleh wali mempelai wanita atau wakilnya dan kabul diucapkan oleh calon mempelai laki-laki, dengan syarat jelas, beruntun, mengguanakan lafal nakaha atau taswij, atau yang semakna, dan ijab kabul masih dalam satu majelis. ${ }^{16}$

Rukun dan syarat perkawinan diatas haruslah terpenuhi. Jika tidak, pernikahan dapat dibatalkan setelah akad nikah dilangsungkan, dikarenakan terdapat pelanggaran perkawinan. Tidak hanya itu, dijelaskan dalam UUP/1974 bahwa perkawinan dapat dibatalkan bila [1] dalam suatu perkawinan masih terdapat ikatan perkawinan yang legal

\footnotetext{
${ }^{12}$ Friedman, Legal System, 16.

${ }^{13}$ Friedman, 14.

${ }^{14}$ Friedman, 17.

15 Jaenal Arifin, Peradilan agama dalam bingkai reformasi hukum di Indonesia (Jakarta: Kencana, 2012), 118.

${ }^{16}$ Muhammad Jazil Rifqi, “Analisis Utilitarianisme Terhadap Dispensasi Nikah Pada Undang-Undang Perkawinan Nomor 1 Tahun 1974," Al-Ahwal: Jurnal Hukum Keluarga Islam 10, no. 2 (2017): 157, https://doi.org/10.14421/ahwal.2017.10204.
} 
di antara salah satu pihak tanpa diketahui pihak yang lain, ${ }^{17}$ [2] perkawinan yang dilangsungkan di muka pegawai pencatat perkawinan yang tidak berwenang, [3] wali nikah yang tidak sah, [4] pernikahan dilangsungkan tanpa dihadiri oleh dua orang saksi, ${ }^{18}$ [5] perkawinan dilangsungkan di bawah ancaman yang melanggar hukum, ${ }^{19}$ [6] bila pada waktu berlangsungnya perkawinan terjadi salah sangka mengenai diri suami atau istri. ${ }^{20}$

Selain regulasi dalam UUP/1974, terdapat pula regulasi dalam Kompilasi Hukum Islam, bahwa perkawinan dapat dibatalkan jika: [1] seorang suami melakukan poligami tanpa izin Pengadilan Agama; [2] perempuan yang dikawini ternyata kemudian diketahui masih menjadi istri pria lain yang mafqud; [3] perempuan yang dikawini ternyata masih dalam masa iddah dari suami sebelumnya; [4] perkawinan yang melanggar batas umur perkawinan sebagaimana ditetapkan dalam pasal 7 UndangUndang No. 1 tahun 1974; [5] perkawinan dilangsungkan tanpa wali atau dilaksanakan oleh wali yang tidak berhak; [6] perkawinan yang dilaksanakan dengan paksaan; ${ }^{21}$ [7] bila perkawinan dilangsungkan di bawah ancaman yang melanggar hukum; ${ }^{22}$ [8] bila pada waktu berlangsungnya perkawinan terjadi penipuan atau salah sangka mengenai diri suami atau istri. ${ }^{23}$ Penipuan disini seperti seorang pria yang mengaku sebagai jejaka, padahal telah mempunyai seorang istri ketika pernikahan dilangsungkan, sedangkan ia melanggar karena poligami tanpa izin Pengadilan Agama atau penipuan atas identitas diri. ${ }^{24}$ Adapun yang dapat mengajukan pembatalan perkawinan adalah orang-orang yang berkepentingan sebagaimana yang tercantum dalam Pasal 23 UUP dan Pasal 73 KHI: 1) Para keluarga dalam garis keturunan lurus ke atas dan ke bawah dari suami/istri, 2) Suami atau istri, 3) Pejabat berwenang yang bertugas mengawasi pelaksanaan perkawinan menurut Undang-Undang, 4) Para pihak yang berkepentingan yang mengetahui adanya cacat dalam rukun dan syarat perkawinan menurut hukum Islam dan peraturan perundang-undangan sebagaimana yang tersebut dalam Pasal 67.

Apabila membahas struktur sistem hukum di Indonesia, di dalamnya termasuk institusi lembaga peradilan atau kekuasaan kehakiman di samping kepolisian dan kejaksaan. ${ }^{25}$ Struktur hukum dalam pembahasan tulisan ini tidak lain adalah Kantor Urusan Agama dan Peradilan Agama. Karena hukum tidak hanya sekedar berupa perundang-undangan atau peraturan-peraturan yang ditetapkan oleh legislatif semata, tetapi hukum juga mengikat kepada institusi-institusi sebagai siapa yang mengeksekusi peraturan tersebut. Struktur hukum disini merupakan kelembagaan penegakan hukum yang mempunyai otoritas pelaksanaan hukum, antara lain Peradilan Agama di bawah naungan Mahkamah Agung yang dalam hal ini menangani Pembatalan Perkawinan, serta Kantor Urusan Agama sebagai pelaksana sebagian tugas Kementerian Agama,

\footnotetext{
${ }^{17}$ Pasal 24 Undang-Undang Perkawinan Nomor 1 tahun 1974.

${ }^{18}$ Pasal 26 ayat (1) Undang-Undang Perkawinan Nomor 1 tahun 1974.

${ }^{19}$ Pasal 27 ayat (1) Undang-Undang Perkawinan Nomor 1 tahun 1974.

${ }^{20}$ Pasal 27 ayat (2) Undang-Undang Perkawinan Nomor 1 tahun 1974.

${ }^{21}$ Pasal 71 Kompilasi Hukum Islam.

${ }^{22}$ Pasal 72 ayat (1) Kompilasi Hukum Islam

${ }^{23}$ Pasal 72 ayat (2) Kompilasi Hukum Islam.

${ }^{24}$ Abdul Manan, ed., Aneka masalah hukum perdata Islam di Indonesia (Jakarta: Kencana, 2012), 46.

${ }^{25}$ Arifin, Peradilan agama, 117.
} 
yaitu yang melangsungkan pencatatan perkawinan. Kewenangan Peradilan Agama dalam menangani sengketa perkawinan tentu saja terdapat pola mengikat diantaranya apa yang menjadi perilaku masyarakat akan menentukan putusan hakim. ${ }^{2627}$ Oleh karenanya tulisan ini perlu dilengkapi sindrom legal reasoning dalam putusan untuk menggambarkan fenomena yang terjadi.

\section{Budaya Hukum Pembatalan Perkawinan dalam Putusan Pengadilan Agama}

Budaya hukum (legal culture) adalah sikap manusia terhadap hukum dan sistem hukum kepercayaan, nilai, pemikiran serta harapannya. Dengan kata lain, kultur hukum adalah suasana pikiran sosial dan kekuatan sosial yang menentukan bagaimana hukum digunakan, dihindari atau disalahgunakan, baik dari penegak hukum maupun dari warga masyarakat. ${ }^{28}$ Perkawinan yang dilaksanakan dengan memberikan keterangan palsu, persaksian palsu, surat-surat palsu atau hal-hal lain sesui ketentuan yang berlaku, maka perkawinan tersebut harus dibatalkan. Sehingga bagi para pihak yang telah ditentukan peraturan perundang-undangan mengetahui adanya cacat hukum, baik karena kurangnya rukun dan syarat pernikahan, atau adanya suatu kebohongan, atau adanya paksaan sebelum akad nikah, pernikahan tersebut wajib dicegah. Selanjutnya jika diketahui setelah akad nikah, maka wajib mengajukan permohonan pembatalan perkawinan kepada institusi yang berwenang. ${ }^{29}$ Peraturan ini menunjukkan rasionalitas kepastian hukumnya bahwa perkawinan yang dilakukan melalui yuridis formal, penghapusan legalitas formal juga harus melalui putusan pengadilan.

Seringkali ditemukakan perkawinan yang telah dibatalkan oleh Pengadilan Agama dalam hal salah sangka, penipuan, atau pemalsuan identitas, misalnya pria tersebut sudah pernah menikah tetapi mengatakan masih jejaka sehingga tidak membutuhkan legalitas izin poligami dari pengadilan, yang pada gilirannya perkawinan tersebut dapat berlangsung. Berikut merupakan beberapa Duduk Perkara dalam Putusan Pengadilan Agama tentang Pembatalan Perkawinan: Putusan Nomor 4960/Pdt.G/2018/PA.Sby. ${ }^{30}$ Pengadilan Agama Surabaya memutuskan dalam perkara pembatalan pernikahan antara pemohon (KUA) yang mengajukan gugatannya pada 12 Oktober 2018 melawan termohon I dan termohon II dengan alasan-alasan sebagai berikut: Pada tanggal 13 September 2018 termohon I dan termohon II telah melangsungkan pernikahan di Kecamatan Krembangan Kota Surabaya setelah dilakukannya pemeriksaan oleh penghulu KUA Kec. Krembangan mengenai syarat-syarat administrinya. Namun, dikemudian hari para pihak termohon mengakui pemalsuan data yang dilakukannya, terutama termohon I terkait status kewarganegaraan sehingga ia kesulitan dalam pengajuan perpanjangan paspor. Karena pengakuan adanya pemalsuan data yang diakui sendiri oleh para termohon tersebut, pernikahan termohon I (WNA Pakistan) dan termohon II (WNI Indonesia) telah melanggar ketentuan undang-undang perkawinan nomor 1 tahun 1974 dalam hal pemalsuan data kewarganegaraan.

\footnotetext{
${ }^{26}$ Friedman, Legal System, 174.

${ }^{27}$ Friedman, The Legal System, 174.

${ }^{28}$ Arifin, Peradilan agama, 119.

${ }^{29}$ Manan, Aneka masalah, 42-45.

${ }^{30}$ Mahkamah Agung RI, "Direktori Putusan Pembatalan Nikah Pengadilan Agama Surabaya," diakses 22 Oktober 2019, https://putusan.mahkamahagung.go.id/pengadilan/pa-surabaya/direktori/perdataagama/pembatalan-nikah.
} 
Putusan Nomor 1050/Pdt.G/2018/PA.Mlg. ${ }^{31}$ Pengadilan Agama Malang telah memeriksa, mengadili dan menjatuhkan putusan dalam perkara pembatalan nikah antara pemohon (kepala KUA) melawan termohon I dan termohon II, bahwa: Termohon I datang ke KUA Kecamatan Kedungkandang kota Malang pada tanggal 13 April 2018 untuk mendaftarkan pernikahan sambil membawa berkas-berkas. Pada tanggal 16 April 2018, termohon I dan termohon II serta Walinya datang ke KUA untuk konfirmasi dan verifikasi data, dan setelah diteliti tidak terdapat data yang bermasalah. Selanjutnya berkas ditandangani ketiganya. Pada 20 April 2018 di KUA Kedungkandang Kota Malang termohon I dan termohon II melangsungkan pernikahan dihadapan petugas dan disaksikan dua orang saksi. Namun, pada tanggal 24 April 2018 datang seorang perempuan bernama AK yang merupakan istri sah, yang telah menikah dengan termohon I di KUA Kecamatan Dander Kabupaten Bojonegoro tanggal 29 Maret 2015. AK di hadapan petugas KUA untuk meminta informasi antara termohon I dan termohon II. Kemudian AK mengklarifikasi kasus ini dengan membawa Surat Pernyataan dari Kepala Desa Dukohkidul Bojonegoro yang menyatakan Surat Keterangan yang digunakan untuk menikahi termohon II adalah palsu atau dipalsukan.

Putusan Nomor 1683/Pdt.G/2017/PA.Mlg. Pengadilan Agama Malang memeriksa, mengadili dan memutuskan perkara pembatalan pernikahan yang diajukan oleh pemohon (Kepala KUA) melawan termohon I dan termohon II. Bahwa Termohon I dan termohon II telah melangsungkan pernikahan pada 27 April 2017 di KUA Kecamatan Sukun Kota Malang. Kemudian selang kurang lebih 2 minggu, ayah dan istri termohon I mendatangi KUA tempat termohon I dan termohon II melangsungkan pernikahan untuk mengkonfirmasi bahwa termohon I masih terikat pernikahan dengan istrinya yang tercatat di KUA Lowokwaru tanggal 28 September 2015, dimana termohon I telah mengajukan cerai talak pada 16 Mei. Namun, perkaranya belum sampai diputus pengadilan. Pengungkapan kebenaran selanjutnya dari termohon I bahwa ia telah melampirkan Akta cerai palsu dalam persyaratan nikah dengan termohon II. Kemudian pemohon (kepala KUA) meminta pembatalan nikah antara termohon I dan termohon II.

Putusan Nomor 1203/Pdt.G/2018.PA.Sda. ${ }^{32}$ Putusan dalam perkara permohonan pembataan nikah yang diajukan oleh pemohon tertanggal 22 Maret 2018 terhadap termohon I, termohon II dan termohon III ini berdasarkan alasan bahwa: Pemohon telah menikah dengan termohon I pada tanggal 13 Maret 2001 dan dikarunia seorang anak berusia 16 tahun dan pada saat itu anak tersebut ikut pemohon. Kemudian pada tanggal 15 April 2008 termohon I dan termohon II melangsungkan nikah di KUA Kecamatan Sidoarjo Kabupaten Sidoarjo dan tinggal di Sidoarjo. Namun, pernikahan antara termohon I dengan termohon II ini ternyata terdapat pemalsuan data, yang ternyata termohon I masih memiliki istri sah dan seorang anak serta belum bercerai. Oleh karenanya, untuk menjaga kepastian hukum dan menghindari penyalahgunaan hukum,

\footnotetext{
${ }^{31}$ Mahkamah Agung RI, "Direktori Putusan Pembatalan Nikah Pengadilan Agama Kota Malang," diakses 22 Oktober 2019, https://putusan.mahkamahagung.go.id/pengadilan/pa-malang/direktori/perdataagama/pembatalan-nikah.

${ }^{32}$ Mahkamah Agung RI, "Direktori Putusan Pembatalan Nikah Pengadilan Agama Sidoarjo," diakses 22 Oktober 2019, https://putusan.mahkamahagung.go.id/pengadilan/pa-sidoarjo/direktori/perdata agama/pembatalan-nikah.
} 
Pengadilan Agama Sidoarjo memerintahkan termohon I dan termohon II untuk menyerahkan kutipan Akta Nikahnya dan memerintahkan KUA Kecamatan Sidoarjo (termohon III) untuk mencoret Buku Kutipan Akta Nikah tersebut dari register Akta Nikah. Tetapi, termohon I dan termohon II dalam kasus ini tidak pernah hadir dalam persidangan untuk dimintai keterangan, pemohon mencabut perkara ini untuk diselesaikan secara kekeluargaan.

Jika pengajuan pembatalan perkawinan yang diajukan oleh pihak sebagaimana tersebut diatas diterima oleh Pengadilan Agama, maka saat mulai berlakunya pembatalan perkawinan itu dihitung sejak tanggal hari putusan Pengadilan Agama dijatuhkan dan putusan itu telah memiliki kekuatan hukum tetap dan berlaku sejak saat berlangsungnya putusan pengadilan. Dengan adanya putusan Pengadilan Agama tersebut, maka berlakulah keadaan semula sebelum perkawinan itu dilaksanakan. Istri tidak akan mendapatkan hak-haknya seperti dalam kasus cerai talak, misalnya, dengan memperoleh nafkah iddah. Hal ini disebabkan bahwa perkawinan yang telah dinyatakan batal demi hukum, pada saat itu pula antara pasangan suami dan istri dianggap sudah tidak memiliki hubungan. Demikian pula status yang perkawinannya dibatalkan ini tidak diatur secara eksplisit (janda/perawan/jejaka/duda) baik dalam UUP maupun KHI, dimana dalam kasus pembatalan perkawinan tidak diberikan surat akta cerai. ${ }^{33}$ Namun pembatalan perkawinan itu tidak berlaku surat terhadap anak-anak yang dilahirkan dari perkawinan tersebut. Meski demikian, kemudaratan dari pembatalan perkawinan juga berdampak terhadap anak-anak yang dilahirkan, meskipun Pasal 76 KHI menguraikan bahwa batalnya perkawinan tidak memutuskan hubungan hukum antara anak dengan orang tuanya. Pasal ini diperuntukkan guna melindungi kemaslahatan dan kepentingan hukum serta masa depan anak-anak yang lahir dari perkawinan yang akan dibatalkan oleh Pengadilan Agama. Walaupun secara psikologis, jika pembatalan perkawinan tersebut benar-benar terjadi, akan membawa dampak negatif atau akibat yang tidak menguntungkan bagi kepentingan anak-anak tersebut. ${ }^{34}$

Dari beberapa putusan pengadilan di atas, nilai objektifitas dengan adanya argumentasi atau alasan hakim dalam memutus perkara pembatalan perkawinan tersebut dimaksudkan sebagai pertanggungjawaban hakim terhadap masyarakat, para pihak serta pengadilan yang lebih tinggi (pasal 23 UU 14/1970, 284 ayat 1, 319 195, 618 Rbg). Betapa pentingnya alasan-alasan sebagai dasar putusan, sehingga putusan yang tidak lengkap atau kurang cukup dipertimbangkan (onvoldoende gemotiveerd) merupakan alasan untuk kasasi dan harus dibatalkan. ${ }^{35}$ Dari duduk perkara diatas, baik siapa yang harus mengajukan permohonan pembatalan perkawinan maupun alasannya dapat dibenarkan secara yuridis. Tetapi, adanya pemalsuan identitas yang dilakukan oleh beberapa orang tersebut, niscaya tujuan perkawinan sebagaimana firman Allah dalam surat Ar-Rum ayat 21 yang menegaskan rumah tangga yang sakinah, mawaddah wa rahmah dan uraian undang-undang perkawinan nomor 1 tahun 1974 yakni membentuk

\footnotetext{
33 Hasyim Nawawie, "Akibat Hukum Pembatalan Perkawinan Di Pengadilan Agama Kabupaten Tulungagung (Studi Perkara No: 0554/PDT.G/2009/PA.TA Dan Perkara No : 0845/PDT.G/2010/PA.TA)," DIVERSI : Jurnal Hukum 2, no. 1 (May 3, 2018): 264, https://doi.org/10.32503/diversi.v2i1.140.

${ }^{34}$ Zainuddin Ali, Hukum Perdata Islam Di Indonesia (Jakarta: Sinar Grafika, 2012), 40.

${ }^{35}$ Sudikno Mertokusumo, Hukum Acara Perdata Indonesia, 5th ed. (Yogyakarta: Liberti, 2002), 15.
} 
keluarga yang kekal dan bahagia niscaya sulit untuk terwujud. Perkawinan tidak hanya fakta manusiawi dan sosial, tetapi lebih dari itu, perkawinan adalah kenyataan religius. ${ }^{36}$ Perkawinan juga tidak hanya penyatuan suami istri, tetapi juga keluarga dari pihak yang bersangkutan. Sehingga pembatalan perkawinan yang diputus majelis hakim merupakan jalan terbaik bagi persona kedua belah pihak jika perkawinan yang cacat hukum dibiarkan akan semakin memperburuk keadaan dikemudian hari. Hal ini sesuai dengan maksim "dar'u al-mafâsid muqaddamun 'alâ jalb al-masâlih", bahwa menolak kerusakan lebih diprioritaskan daripada mendatangkan kemaslahatan.

Pendekatan untuk mengangkat wanita dari tempat, kehidupan, dan pengalamannya dalam restorasi legal merupakan isu yang sulit terwujud. Dengan ungkapan lain, budaya hukum masih mendiskriminasikan wanita. Penyangkalan penderitaan wanita datang dari berbagai bentuk, tetapi hasilnya adalah selalu sama, dianggap masalah yang tidak serius. Nyatanya, wanita dapat terintimidasi dengan mudah karena faktor biologisnya. Perbedaan sifat kewanitaan tersebut seringkali belum diakui dalam sistem hukum. Ketika wanita hamil, kehidupan biologisnya mencakup kehidupan embrio kehidupan janinnya. Ketika dia memelihara anaknya, kebutuhan kehidupannya juga mencakup anaknya. Bagi wanita, pengalamannya jelas berbeda dari laki-laki, termasuk pengalaman fisik, emosional dan psikologisnya. Ketidaksamaan hukum tersebut dapat dikoreksi atas terciptanya hukum pada masa awal pembentukannya, yang problem fundamentalnya adalah sistem legal mengabadikan hirarki gender subordinasi wanita dari laki-laki. ${ }^{37}$

\section{Alternatif Pencegahan Pemalsuan Identitas dalam Perkawinan}

Institusi penyelenggara pernikahan, yang dalam hal ini seluruh jajaran KUA seyogyanya memahami perundang-undangan tentang pernikahan secara matang. Sehingga dalam memeriksa kelengkapan berkas calon suami istri tidak sampai terjadi pengelabuan oleh masyarakat yang tidak bertanggungjawab. Hal ini tidak lain adalah upaya agar sedapat mungkin tidak terjadi pelanggaran terhadap ketentuan agama dan perundang-undangan. Pegawai Pencatat Nikah tidak hanya bertugas untuk mencatatkan perkawinan saja, tetapi juga memiliki tugas untuk mengawasi terhadap adanya pelanggaran perkawinan antara calon mempelai pasutri. Untuk menghindari akan terjadinya pelanggaran sebelum ijab qabul, perkawinan dapat dicegah jika terdapat pihak yang tidak memenuhi syarat-syarat melangsungkan perkawinan.

Pencegahan perkawinan dilakukan bila tidak memenuhi dua persyaratan. Pertama, syarat materiil adalah syarat yang berkaitan dengan pencatatan perkawinan, Akta nikah, dan sebab-sebab terjadinya larangan perkawinan. Kedua, syarat administratif adalah syarat perkawinan yang melekat pada setiap rukun perkawinan, yang meliputi calon mempelai laki-laki dan wanita, saksi, wali dan pelaksanaan akad nikahnya, juga harus diperhatikan. Tentu saja, identifikasi Pegawai Pencatat Nikah sangat dibutuhkan terhadap calon mempelai yang memiliki larangan pernikahan untuk menolak perkawinannya disertai dengan alasan-alasan penolakannya. Pencegahan perkawinan berdasarkan Undang-Undang Perkawinan dan Kompilasi Hukum Islam

\footnotetext{
${ }^{36}$ Moses Komela Avan, Kebatalan Perkawinan, 16.

37 Judith E Tucker, Women, Family, and Gender in Islamic Law (Cambridge: Cambridge University Press, 2008), 5-6.
} 
bernuansa menutup kemungkinan munculnya kemudaratan terhadap pihak-pihak yang akan melangsungkan perkawinan. Jika demikian halnya, persoalan mengenai kesadaran masyarakat terhadap hukum perkawinan yang menjadi faktor terwujudnya ketertiban administrasi dan tertib hukum dalam masyarakat akan mengalami perbaikan. ${ }^{38}$ Disini, Undang-Undang Perkawinan dan KHI lebih mengutamakan pencegahan terjadinya perkawinan yang tidak memenuhi persyaratan, karena jika suami-istri telah berumah tangga dan memiliki keturunan, kemudian terjadi pembatalan perkawinan, kejadian tersebut akan lebih memudaratkan kedua belah pihak, termasuk keluarga, kerabat, dan keturunannya. ${ }^{39}$

Sistem hukum, dengan demikian, bagaimanapun harus menjaga dan melestarikan aturan diskresi dalam batasan-batasan yang tepat. ${ }^{40}$ Apabila sistem pencegahan tidak bisa terlaksana, sanksi adalah cara untuk mengimplementasikan norma hukum. Sanksi hukum adalah sanksi yang ditentukan atau disahkan oleh undang-undang. Setiap aturan hukum mengandung atau menyiratkan pernyataan konsekuensi hukum. Dalil yang harus diambil kebenarannya adalah hadirnya sanksi hukum dapat mengancam seseorang. Jika sanksi dihadirkan atau bahkan dilaksanakan, perilaku seseorang untuk melakukan pemalsuan data dalam perkawinan akan menurun. Tentu saja ancaman adanya hukuman ini cenderung sebagai pencegahan atau sosial kontrol dari perbuatan terlarang. ${ }^{41}$ Bentuk hukuman yang umum dalam hukum pidana adalah denda atau penjara. ${ }^{42}$ Namun, hukuman penjara dalam kasus semacam ini tidak layak untuk diselenggarakan, karena dapat berakibat pada masa depan para pelaku, ${ }^{43}$ yakni diantaranya sulitnya mendapatkan pekerjaan, atau bahkan sifat/karakter manusiawinya akan semakin memburuk seiring berkumpulnya sesama narapidana.

Dalam penjelasan PP No. 9 tahun 1975 tentang Pelaksanaan Undang-Undang Nomor 1 tahun 1974 tentang Perkawinan pasal 45 diatur tentang sanksi hukuman denda bagi pihak mempelai yang melanggar ketentuan Pasal 3, 10 ayat (3) dan 40, dan sanksi hukuman kurungan atau denda bagi pejabat pencatat perkawinan yang melanggar ketentuan Pasal 6, 7, 8, 9, 10 ayat (1), 11,13, dan 44. Pejabat yang melanggar ketentuan tersebut dihukum dengan hukuman kurungan selama-lamanya 3 (tiga) bulan atau denda setinggi-tingginya Rp.7.500,-(tujuh ribu lima ratus rupiah). Tidak ada hal yang signifikan terhadap pasal-pasal sanksi terhadap calon mempelai, namun yang sangat perlu diperhatikan adalah kejelian bagi pegawai pencatat perkawinan mengenai syarat-syarat perkawinan apakah telah dipenuhi dan tidak terdapat halangan perkawinan menurut undang-undang (pasal 6). Jika tidak teliti, tentu saja menurut undang-undang ini yang mendapat sanksi adalah pegawai pencatat perkawinan. Sayangnya, penerapan sanksi terhadap pelanggaran undang-undang perkawinan hampir tidak dimulai dan belum menemukan titik terangnya siapa yang akan mengeksekusi. Padahal, basis filsafat dibalik hukuman adalah membangkitkan hak asasi manusia dan juga usaha untuk menurunkan ketidakadilan dalam berumah-tangga. Seperangkat hukuman yang

\footnotetext{
${ }^{38}$ Ali, Hukum Perdata Islam Di Indonesia, 33-37.

${ }^{39}$ Beni Ahmad Saebani, Fiqh Munakahat, vol. 2 (Bandung: Pustaka Setia, 2009), 117.

${ }^{40}$ Friedman, Legal System, 35.

${ }^{41}$ Friedman, 70-71.

42 Friedman, 77.

${ }^{43}$ Friedman, 103.
} 
dihadirkan tentu saja memiliki tujuan yang tidak lain adalah untuk mencegah perilaku kriminal pada masa selanjutnya.

Ada pendekatan tradisional untuk memberikan justifikasi rasional terhadap praktik kriminal dalam keluarga. Semua versi utilitarianisme mengawali dari premis kewajiban moral dasar bahwa melestarikan kemaslahatan (kebahagiaan / kebaikan) dan menghilangkan kemudaratan (kesengsaraan / keburukan). Kemaslahatan utilitarian ini tidak merujuk pada individu atau pribadi seseorang semata, melainkan lebih diperuntukkan pada publik. Jika terdapat ambiguitas mana yang harus dipilih antara kemaslahatan atau kemudaratan, maka harus diprioritaskan yang memiliki kebaikan lebih besar daripada keburukan, serta mengkalkulasi bagaimana konsekuensi jangka panjang dan jangka pendeknya. John Stuart Mill mempercayai bahwa kemaslahatan terbesar hanya dapat dicapai dengan memberikan kesempatan pada perkembangan intelektual. Beberapa Ide sanksi kiranya yang menyebabkan rasa sakit bagi pelaku kriminal, baik berupa melayani publik, denda, atau kurungan penjara. Hukuman ini, dalam pembuktian utilitarian, setidaknya mereduksi dan mencegah kejahatan yang sama di masa depan. Selain itu, rehablitasi moral juga tepat untuk diimplementasikan sebagai upaya merubah karakter untuk menjadi lebih baik. Retributrivisme juga sebagai tawaran alternatif utama dari teori utilitarian untuk pencegahan. Teori retribusi ini mengatakan bahwa justifikasi sanksi adalah untuk menemukan sifat esensi tindak kriminal, bukan konsekuensinya, jika tindakannya adalah kesalahan moral. Retribusi melihat kebelakang untuk menentukan faktor utama kesalahan seseorang. ${ }^{44}$ Meski demikian, prinsip yang telah dikembangkan dalam konteks hukum pidana tersebut tentu saja tidak mudah untuk diterapkan pada hukum perdata (keluarga) yang memang tidak memiliki fungsi mandatori. ${ }^{45}$

Dalam kata pengantar Prof. Dr. Jimly Asshiddiqie, untuk merelevankan sistem hukum yang sesuai dengan keadaan hukum di Indonesia masih terdapat kekurangan dalam teori Lawrence M. Friedman (substansi hukum, struktur hukum, dan budaya hukum). Oleh karenanya perlu ditambahkan dengan komponen baru, yaitu hadirnya sistem informasi dan kepemimpinan yang tidak terpisahkan. ${ }^{46}$ Ada berbagai metode yang bisa diterapkan untuk mencegah terjadinya manipulasi data oleh pihak yang tidak bertanggung jawab. Diantaranya adalah mengintegrasikan data kependudukan yang berada di pelosok-pelosok desa dengan pusat, sehingga dapat mempercepat efisiensi pengawasan data. Selain itu, kepemimpinan yang baik adalah dengan mendisiplinkan bawahannya dengan memperketat pelaksanaan SOP, agar tidak terjadi kesalahan yang sama di lain waktu. Terlebih dengan terus mengupayakan langkah prefentif dalam rangka pencegahan, penangkalan, pengendalian sebelum terjadinya pemalsuan identitas seperti dengan memberikan penyuluhan hukum kepada masyarakat oleh pejabat berwenang untuk lebih dioptimalkan. Signifikansi penyuluhan hukum bagi masyarakat agar memiliki kesadaran hukum sehingga dapat mematuhi dan menghargai hukum yang berlaku.

\footnotetext{
${ }^{44}$ Laurence D. Houlgate, Philosophy, Law and the Family: A New Introduction to the Philosophy of Law. (Place of publication not identified: SPRINGER, 2019), 116-20.

45 Houlgate, 100.

${ }^{46}$ Ahmad Tholabi Kharlie, Hukum Keluarga Indonesia (Jakarta: Sinar Grafika, 2013), xviii.
} 


\section{Kesimpulan}

Bentuk pemalsuan identitas tersebut sudah jauh kehilangan rasionalitasnya dan sudah tidak dapat diaplikasikan dalam sistem sosial hari ini. Akad nikah yang dilangsungkan secara tidak sesuai dengan peraturan-peraturan yang berlaku adalah perbuatan yang nihil, bahkan perbuatan tersebut melanggar hukum yang harus dicegah oleh siapapun yang mengetahuinya, atau dengan cara pembatalan apabila pernikahan itu telah dilaksanakan. Posisi tersebut menjelaskan bahwa perubahan sosial dan kultur dalam masyarakat mempengaruhi nilai-nilai dalam perkawinan seperti halnya pemalsuan identas ini, yang mengharuskan rekonstruksi dalam nilai-nilai ini sehingga mampu menjalankan pelayanan hukum yang lebih baik lagi. Fenomana semacam ini memang diketahui, diakui, dan disadari eksistensinya, tetapi tidak sepenuhnya diselesaikan dengan segera. Gagasan sistem hukum Lawrance M Friedman sebagaimana yang telah diuraikan diatas, dan penambahan ide dari Jimly Asshiddiqie adalah tawaran yang yang apabila diaplikasikan bisa menunjang kinerja kepada struktur hukum nuntuk menjadi Good Governance.

\section{Daftar Pustaka}

Abdurrahman. Kompilasi hukum Islam di Indonesia. Jakarta: Akademika Pressindo, 2010.

Ali, Zainuddin. Hukum Perdata Islam Di Indonesia. Jakarta: Sinar Grafika, 2012.

Arifin, Jaenal. Peradilan agama dalam bingkai reformasi hukum di Indonesia. Jakarta: Kencana, 2012.

Button, Kirsty, Elena Moore, and Chuma Himonga. "South Africa's System of Dispute Resolution Forums: The Role of the Family and the State in Customary Marriage Dissolution." Journal of Southern African Studies 42, no. 2 (March 3, 2016): 299-316. https://doi.org/10.1080/03057070.2016.1148390.

Faisal, Faisal. "Pembatalan Perkawinan Dan Pencegahannya." Al-Qadha 4, no. 1 (August 23, 2017): 1-15.

Friedman, Lawrence M. Legal System, The: A Social Science Perspective. New York: Russell Sage Foundation, 1975.

Hoerudin, Ahrum. Pengadilan agama: bahasan tentang pengertian, pengajuan perkara, dan kewenangan pengadilan agama setelah berlakunya UU No. 7 Tahun 1989 Tentang Peradilan Agama. Bandung: Citra Aditya Bakti, 1999.

Holik, Abd. "Pembatalan Perkawinan Akibat Poligami." Tafáqquh: Jurnal Penelitian Dan Kajian Keislaman 1, no. 2 (December 1, 2013): 58-72.

Houlgate, Laurence D. Philosophy, Law and the Family: A New Introduction to the Philosophy of Law. Place of publication not identified: SPRINGER, 2019.

Ismayawati, Any. "Pengaruh Budaya Hukum Terhadap Pembangunan Hukum Di Indonesia (Kritik Terhadap Lemahnya Budaya Hukum Di Indonesia)." PRANATA HUKUM 6, no. 1 (January 31, 2011). http://jurnal.ubl.ac.id/index.php/PH/article/view/154.

Kharlie, Ahmad Tholabi. Hukum Keluarga Indonesia. Jakarta: Sinar Grafika, 2013.

Kompilasi Hukum Islam diserbarluaskan melalui Instruksi Presiden Ri No 1 Tahun 1991 
Mahkamah Agung RI. "Direktori Putusan Pembatalan Nikah Pengadilan Agama Kota Malang." Accessed $\quad$ October 2019. https://putusan.mahkamahagung.go.id/pengadilan/pa-malang/direktori/perdataagama/pembatalan-nikah.

. "Direktori Putusan Pembatalan Nikah Pengadilan Agama Sidoarjo." Accessed October 22, 2019. https://putusan.mahkamahagung.go.id/pengadilan/pasidoarjo/direktori/perdata agama/pembatalan-nikah.

. "Direktori Putusan Pembatalan Nikah Pengadilan Agama Surabaya." Accessed October 22, 2019. https://putusan.mahkamahagung.go.id/pengadilan/pasurabaya/direktori/perdata-agama/pembatalan-nikah.

Manan, Abdul, ed. Aneka masalah hukum perdata Islam di Indonesia. Jakarta: Kencana, 2012.

Mertokusumo, Sudikno. Hukum Acara Perdata Indonesia. 5th ed. Yogyakarta: Liberti, 2002.

Moses Komela Avan, R. D. Kebatalan Perkawinan : Pelayanan Hukum Gereja Dalam Proses Menyatakan Kebatalan Perkawinan. Yogyakarta: Kanisius, 2014.

Nawawie, Hasyim. "Akibat Hukum Pembatalan Perkawinan Di Pengadilan Agama Kabupaten Tulungagung (Studi Perkara No: 0554/PDT.G/2009/PA.TA Dan Perkara No: 0845/PDT.G/2010/PA.TA)." DIVERSI : Jurnal Hukum 2, no. 1 (May 3, 2018): 259-87. https://doi.org/10.32503/diversi.v2i1.140.

Rahmatillah, Deni, and A. N. Khofify. "Konsep Pembatalan Perkawinan Dalam Undang-Undang Nomor 1 Tahun 1947 Dan Kompilasi Hukum Islam." Hukum Islam 17, no. 2 (March 29, 2018): 152-71. https://doi.org/10.24014/hi.v17i2.4985.

Rifqi, Muhammad Jazil. "Analisis Utilitarianisme Terhadap Dispensasi Nikah Pada Undang-Undang Perkawinan Nomor 1 Tahun 1974." Al-Ahwal: Jurnal Hukum Keluarga Islam 10, no. 2 (2017): $156-64$. https://doi.org/10.14421/ahwal.2017.10204.

Saebani, Beni Ahmad. Fiqh Munakahat. Vol. 2. Bandung: Pustaka Setia, 2009.

Tucker, Judith E. Women, Family, and Gender in Islamic Law. Cambridge: Cambridge University Press, 2008.

Undang-Undang Nomor 1 Tahun 1974 tentang Perkawinan LN Tahun 1974 No. 1 